\title{
Insecticide resistance profiles of Anopheles gambiae s.l. in Togo and genetic mechanisms involved, during 3-year survey: is there any need for resistance management?
}

Adjovi D. Amoudji ${ }^{*}$, Koffi M. Ahadji-Dabla ${ }^{1,2^{*}}$, Aristide Sawdetuo Hien ${ }^{3}$, Yawo Georges Apétogbo ${ }^{1}$, Bienvenu Yaméogo ${ }^{3}$, Diloma Dieudonné Soma ${ }^{3}$, Rabila Bamogo ${ }^{3}$, Rachid Tinah Atcha-Oubou ${ }^{4}$,

Roch Kounbobr Dabiré ${ }^{3}$ and Guillaume Koffivi Ketoh ${ }^{1}$

\begin{abstract}
Background: Malaria, one of the world's greatest public health challenges, is an endemic disease with stable transmission in Togo. Combating malaria requires an effective vector control. This study provides temporal data on insecticide resistance status in the major malaria vector Anopheles gambiae sensu lato (s.l.) from Togo.

Methods: Two to 5 days old females of An. gambiae s.l., originating from three localities (Baguida, Kovié, Kolokopé) were subjected to insecticide-impregnated papers during 3 years $(2012,2013,2016)$ as follows: organochlorides $(4 \%$ DDT), pyrethroids ( $0.05 \%$ deltamethrin, $0.75 \%$ permethrin, $0.05 \%$ lambdacyhalothrin), carbamates ( $0.4 \%$ bendiocarb and $0.1 \%$ propoxur), and organophosphates ( $5 \%$ malathion, $0.4 \%$ chlorpyrifos methyl, $1 \%$ fenitrothion) following the WHO standard protocol. Dead and surviving mosquitoes were stored separately in Eppendorf tubes containing silica gel for DNA extraction, species identification, and $k d r$ and ace- 1 genotyping.
\end{abstract}

Results: Knockdown times (KDT 50 and $\mathrm{KDT}_{95}$ ) were high in An. gambiae s.l. The lowest KDTs were recorded at Baguida in 2013 for deltamethrin (KDT $50=24.7, \mathrm{Cl}$ [22.4-27.12] and $\mathrm{KDT}_{95}=90.78, \mathrm{Cl}$ [76.35-113.49]). No KDTs were recorded for DDT and in some instances for permethrin. In general, An. gambiae s.l. was resistant to most of the four classes of insecticides during the survey periods regardless of locality and year, except to chlorpyrifos methyl. In some instances, mosquitoes were fully susceptible to fenitrothion (Kolokopé: 100\% and Kovié: 98.05\%, Cl [95.82-100.26]) and malathion (100\% at both Kolokopé and Kovié) in 2013, and malathion only (Kolokopé; 100\%) in 2016. Anopheles coluzzii, An. gambiae and Anopheles arabiensis were the three sibling species identified at the three localities with some hybrids at Baguida (2013), and Kovié (2012 and 2016), respectively. Anopheles gambiae was relatively dominant (61.6\%). The kdr $1014 \mathrm{~F}$ allele frequency was $>0.9 \mathrm{in}$ most of the cases, except at Kolokopé ( $f(1014 \mathrm{~F})=0.63, \mathrm{Cl}[0.55-0.71])$ in 2013. The kdr 1014S allele frequency was below 0.02. The highest ace-1 frequencies were identified in An. gambiae at Baguida (2012: 0.52, Cl [0.34-0.69] and 2013: 0.66, Cl [0.46-0.86]).

Conclusion: The resistance status is worrying in Togo and should be considered in future malaria vector resistance management programmes by decision-makers.

Keywords: Malaria, Anopheles gambiae s.l., Resistance, kdr, ace-1, Vector control, Togo

\footnotetext{
*Correspondence: amoudjifa@gmail.com; km.ahadjidabla@gmail.com

${ }^{1}$ Department of Zoology and Animal Biology, Faculty of Sciences,

University of Lomé, 01 B.P. 1515 Lomé 01, Togo

Full list of author information is available at the end of the article
} 


\section{Background}

Although the global response to malaria was considered one of the world's greatest public health achievements, the overall decline in the global malaria burden has levelled off [1]. In 2017, there were an estimated 219 million cases of malaria worldwide, mostly occurring in the World Health Organization (WHO) African Region (92\%) [2].

In Togo, malaria is endemic with a stable transmission [3]. The control of the disease is one of the Ministry of Health's priorities [4]. Since 1998, Togo has adhered to the Roll Back Malaria (RBM) Initiative launched in October 1998, with the objective to reduce the malaria burden which represents an obstacle to development in endemic countries, by 2030. Malaria control in Togo focuses mainly on two strategies implemented by the National Malaria Control Programme (NMCP), including prevention and clinical management. Despite efforts to overcome the scourge, malaria remains a major public health concern. In 2016, it was reported by the NMCP that malaria morbidity was $38 \%$ of outpatient consultations and $17 \%$ of hospital admissions; children under 5 years of age were the most affected. Mortality in infants was $67.7 \%$ [5].

The primary tool for malaria vector control in Togo is long-lasting insecticide-treated bed nets (LLINs) [6]. Other means, including mosquito coils and aerosols, are also used by households [7]. However, insecticide resistance in malaria vector populations widespread in West Africa, could impede the success of malaria control programmes in general. In Togo, reports have indicated resistance of Anopheles gambiae sensu lato (s.l.), the major malaria vector, to the four classes of insecticides available for public health $[5,7-10]$.

Both enhanced detoxification [11] and mutations in the gene encoding the voltage-gated sodium channel knockdown resistance $(k d r)$, and insensitive acetylcholinesterase (ace-1) [12] have been reported as the most important mechanisms involved in insecticide resistance. Two amino acid changes in the sodium channel gene at codon 1014 are involved in $k d r$ in An. gambiae s.s.: a leucine to phenylalanine substitution (1014F) [13] and a leucine to serine substitution (1014S) [14]. Consequently, target site mutations (i.e., 1014F and 1014S) confer resistance to pyrethroids and DDT in An. gambiae sensu stricto (s.s.). Insensitive acetylcholinesterase gene confers resistance to both organophosphates and carbamates in An. gambiae s.s. through a single amino acid substitution of glycine to serine at position 119 [15].

Malaria vector resistance, which is widespread in Africa, particularly in Benin [16-18], Burkina Faso [1921], Ghana [22, 23], Cameroon [24, 25], and Kenya [26], constitutes the first challenge to achieving a decline in malaria cases. Hence, knowledge of insecticide resistance is a basic requirement that will guide the use of insecticides in malaria control programmes. This study presented a 3-year survey of insecticide resistance profiles of An. gambiae s.l. in three agricultural localities of Togo. Dynamics of An. gambiae species and the frequency of $k d r$ (L1014F and L1014S) and ace-1 mutations were also investigated.

\section{Methods}

\section{Study area}

This study was conducted at three localities characterized by different agricultural ecosystems in Togo: Baguida, Kovié, and Kolokopé (see Fig. 1). Baguida $\left(06^{\circ} 09^{\prime} 47^{\prime \prime} \mathrm{N}-01^{\circ} 19^{\prime} 05^{\prime \prime} \mathrm{E}\right)$ is a peri-urban area with vegetable production located at the coastal part of Togo. Kovié $\left(06^{\circ} 34^{\prime} 38^{\prime \prime} \mathrm{N}-01^{\circ} 11^{\prime} 47^{\prime \prime} \mathrm{E}\right)$ is a rural area mainly characterized by rice cultivation. This locality is $30 \mathrm{~km}$ from Lomé. Baguida and Kovié are located at the southern part (Région Maritime) of the country. Kolokopé $\left(06^{\circ} 34^{\prime} 38^{\prime \prime} \mathrm{N}-01^{\circ} 11^{\prime} 47^{\prime \prime} \mathrm{E}\right)$, a cotton-growing area is a rural locality $250 \mathrm{~km}$ from Lomé in the highlands (Région des Plateaux) of Togo.

The south of Togo is characterized by a sub-equatorial climate with two dry seasons (December to March and August to September) and two rainy seasons (April to July and October to November). The highlands are characterized by a microclimate commonly known as mountain climate.

\section{Mosquito collection}

Different instar larvae of An. gambiae s.l. were collected over a period of 3 years (i.e., 2012, 2013, 2016) at Kolokopé, Kovié and Baguida. Larvae were sampled between June and July of each year during the rainy season from permanent and semi-permanent water collection points and pooled together by locality. Samples were transported to the insectary for rearing under standard conditions $\left(25 \pm 2{ }^{\circ} \mathrm{C}, 80 \pm 4 \%\right.$ [relative humidity]).

\section{Insecticide susceptibility assays}

Two to 5 days old $F_{0}$ female mosquitoes were used for insecticide susceptibility tests. Insecticide bioassays were conducted following the WHO protocol $[27,28]$. The following insecticides were tested: organochlorides $(4 \%$ DDT), pyrethroids (0.05\% deltamethrin, $0.75 \%$ permethrin, $0.05 \%$ lambdacyhalothrin), carbamates $(0.4 \%$ bendiocarb and $0.1 \%$ propoxur), and organophosphates $(5 \%$ malathion, $0.4 \%$ chlorpyrifos methyl, $1 \%$ fenitrothion).

Twenty to 25 unfed females were randomly selected and exposed to each impregnated paper for $1 \mathrm{~h}$, except for fenitrothion which exposure time was $2 \mathrm{~h}$. The knockdown effect of pyrethroids and DDT were observed 


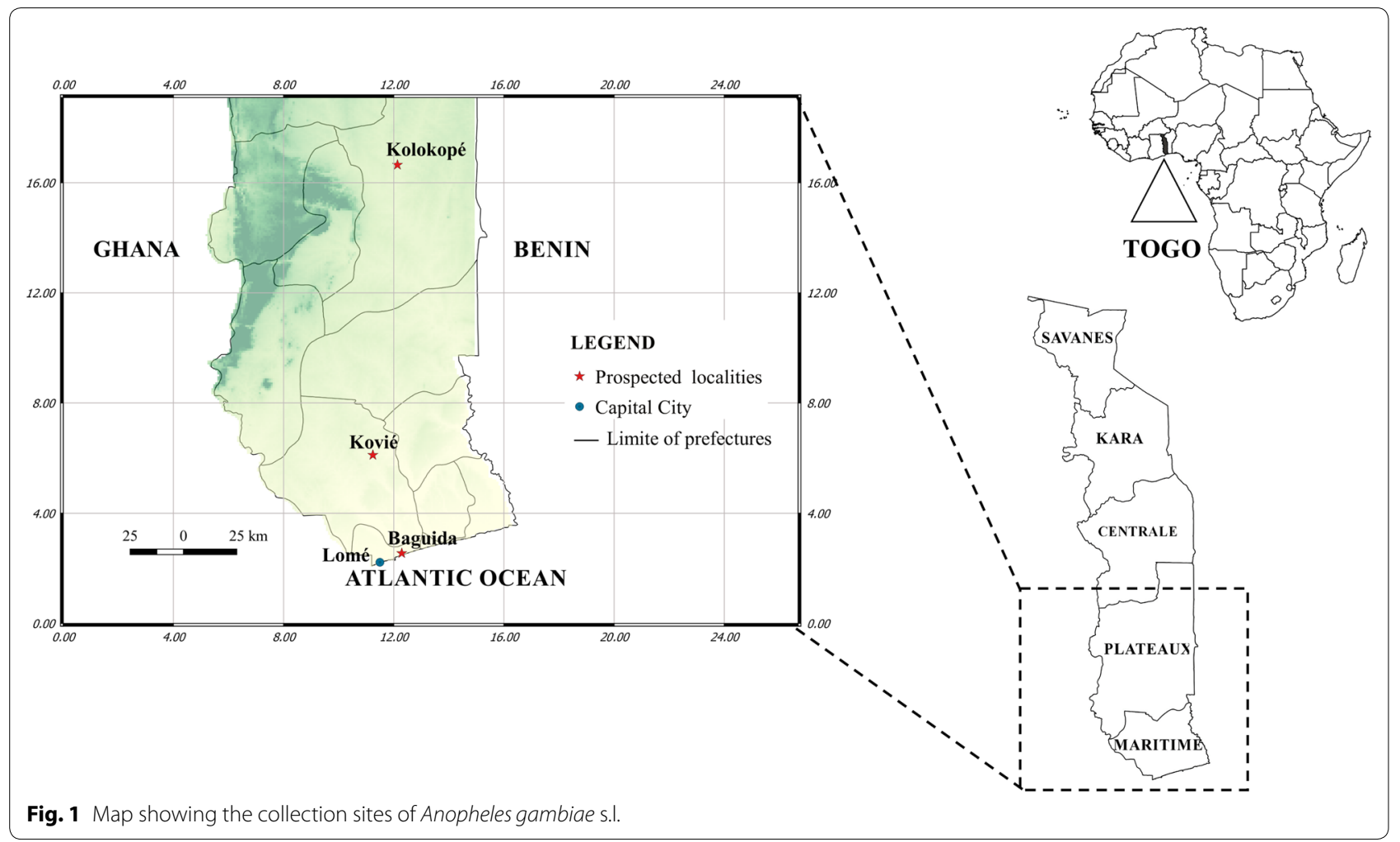

every $10 \mathrm{~min}$ for $1 \mathrm{~h}$ and individuals knocked down were recorded. A susceptible Kisumu strain of An. gambiae was used as a reference for the bioassays. Before their exposition, the mosquitoes were observed for $1 \mathrm{~h}$ in holding tubes. After exposure, the mosquitoes were transferred to the holding tubes and fed with $10 \%$ glucose solution $[27,28]$. Dead individuals were recorded 24-h post-exposure. A total of $5888 \mathrm{~F}_{0}$ female mosquitoes were used for the bioassays: Baguida $(n=2067)$, Kovié $(\mathrm{n}=1932)$ and Kolokopé $(\mathrm{n}=1889)$ (see Table 1$)$. Dead and surviving mosquitoes were stored separately in Eppendorf tubes containing silica gel and transported to Institut de Recherche en Sciences de la Santé (IRSS, BoboDioulasso, Burkina Faso) for species identification and resistance mechanism characterization.

\section{Anopheles gambiae s.I. species identification}

Each mosquito's DNA was extracted from head and thorax with $2 \%$ cetyl trimethyl ammonium bromide (2\% CTAB). Anopheles gambiae s.l. was identified to species by PCR according to the method of Santolamazza et al. [29].

Species identification was performed by PCR-SINE200 technique. The extracted DNA was amplified in $20 \mu \mathrm{l}$ of a master mixture. Two specific primers were used: (5'-TCG-CCT TAG ACC TTG CGT TA-3'), (5'-CGC TTC AAG AAT TCG AGA TAC-3'). The amplification conditions were as follows: an initial step of activation of the DNA polymerase for $10 \mathrm{~min}$ at $94{ }^{\circ} \mathrm{C}$ followed by 35 cycles at $94{ }^{\circ} \mathrm{C}$ for $30 \mathrm{~s}$, a hybridization at $54{ }^{\circ} \mathrm{C}$ for $30 \mathrm{~s}$ and at $72{ }^{\circ} \mathrm{C}$ for $1 \mathrm{~min}$ and a final elongation at $72{ }^{\circ} \mathrm{C}$ for $10 \mathrm{~min}$ followed by a decrease in temperature to $4{ }^{\circ} \mathrm{C}$. The amplified products were analysed by electrophoresis on $2 \%$ agarose gel and stained with ethidium bromide and visualized under UV light. The following band sizes distinguish the species of the An. gambiae complex: 479 bp fragment for An. coluzzii, 249 bp for An. gambiae and $223 \mathrm{bp}$ for An. arabiensis.

\section{Kdr and ace-1 molecular genotyping}

The presence of $k d r$ 1014F and 1014S alleles also known as $k d r$-west $(k d r-w)$ and $k d r$-east $(k d r-e)$, respectively, were detected, respectively, by the methods of Martinez-Torres et al. [13] and Ranson et al. [14]. Presence of G119S ace-1 mutation was also investigated using the method of Weill et al. [15].

The West African kdr L1014F mutation was detected using the common primers Agd1 (5'-ATA GAT TCC CCG ACC ATG-3') and Agd2 (5'-AGA CAA GGA TGA TGA ACC-3'), and Agd3 (5'-AAT TTG CAT TAC TTA CGA CA-3') the susceptible primer and Agd4 (5'-CTG TAG TGA TAG GAA ATT TA-3') the resistance primer. Amplification was performed under the following temperature conditions: DNA polymerase activation step 
Table 1 Susceptibility status of An. gambiae s.l. collected in Togo and Kisumu exposed to the four classes of insecticide

\begin{tabular}{|c|c|c|c|c|c|c|}
\hline Year & Insecticides & Strain & $\mathbf{N}$ & Mortality (\%) & {$[95 \% \mathrm{Cl}]$} & Susceptibility status \\
\hline \multirow[t]{16}{*}{2012} & \multirow[t]{4}{*}{$4 \%$ DDT } & Baguida & 103 & 10.68 & {$[2.71-18.23]$} & Resistant \\
\hline & & Kolokopé & 95 & 0 & 0 & Resistant \\
\hline & & Kovié & 98 & 1.02 & {$[0.15-3.22]$} & Resistant \\
\hline & & Kisumu & 103 & 100 & 100 & Susceptible \\
\hline & \multirow[t]{4}{*}{ 0.05\% Deltamethrin } & Baguida & 99 & 32.32 & [23.23-41.62] & Resistant \\
\hline & & Kolokopé & 101 & 3.96 & {$[0.77-6.93]$} & Resistant \\
\hline & & Kovié & 95 & 33.68 & {$[20.2-46.4]$} & Resistant \\
\hline & & Kisumu & 98 & 100 & 100 & Susceptible \\
\hline & \multirow[t]{4}{*}{$0.1 \%$ Bendiocarb } & Baguida & 96 & 7.29 & {$[1.19-13.8]$} & Resistant \\
\hline & & Kolokopé & 99 & 89.89 & [82.32-97.42] & Resistant \\
\hline & & Kovié & 94 & 60.63 & {$[45.77-76.48]$} & Resistant \\
\hline & & Kisumu & 106 & 100 & 100 & Susceptible \\
\hline & \multirow[t]{4}{*}{ 0.4\% Chlorpyriphos methyl } & Baguida & 100 & 100 & 100 & Susceptible \\
\hline & & Kolokopé & 103 & 100 & 100 & Susceptible \\
\hline & & Kovié & 106 & 100 & 100 & Susceptible \\
\hline & & Kisumu & 97 & 100 & 100 & Susceptible \\
\hline \multirow[t]{28}{*}{2013} & \multirow[t]{4}{*}{$4 \%$ DDT } & Baguida & 97 & 6.18 & {$[0.76-12.23]$} & Resistant \\
\hline & & Kolokopé & 96 & 0 & 0 & Resistant \\
\hline & & Kovié & 90 & 15.55 & [7.16-22.96] & Resistant \\
\hline & & Kisumu & 99 & 100 & 100 & Susceptible \\
\hline & \multirow[t]{4}{*}{ 0.05\% Deltamethrin } & Baguida & 87 & 52 & {$[46.71-56.64]$} & Resistant \\
\hline & & Kolokopé & 74 & 14.86 & [7.79-21.92] & Resistant \\
\hline & & Kovié & 90 & 22.22 & [12.32-32.88] & Resistant \\
\hline & & Kisumu & 101 & 100 & 100 & Susceptible \\
\hline & \multirow[t]{4}{*}{ 0.75\% Permethrin } & Baguida & 89 & 20.22 & {$[5.15-37.39]$} & Resistant \\
\hline & & Kolokopé & 80 & 7.5 & {$[0.98-14.3]$} & Resistant \\
\hline & & Kovié & 90 & 26.26 & [14.58-39.68] & Resistant \\
\hline & & Kisumu & 98 & 100 & 100 & Susceptible \\
\hline & \multirow[t]{4}{*}{ 0.05\% Lambdacyhalothrin } & Baguida & 90 & 57.77 & [51.15-64.69] & Resistant \\
\hline & & Kolokopé & 85 & 0 & 0 & Resistant \\
\hline & & Kovié & 81 & 14.81 & {$[1.65-28.21]$} & Resistant \\
\hline & & Kisumu & 108 & 100 & 100 & Susceptible \\
\hline & \multirow[t]{4}{*}{$0.1 \%$ Bendiocarb } & Baguida & 87 & 9.19 & [0.58-18.33] & Resistant \\
\hline & & Kolokopé & 88 & 98.86 & [96.92-101] & Susceptible \\
\hline & & Kovié & 93 & 68.81 & [59.84-77.1] & Resistant \\
\hline & & Kisumu & 102 & 100 & 100 & Susceptible \\
\hline & \multirow[t]{4}{*}{$0.1 \%$ Propoxur } & Baguida & 95 & 18.94 & [10.3-26.95] & Resistant \\
\hline & & Kolokopé & 97 & 97.93 & [95.65-100.27] & Suspected resistant \\
\hline & & Kovié & 89 & 73.03 & {$[63.28-82.42]$} & Resistant \\
\hline & & Kisumu & 98 & 100 & 100 & Susceptible \\
\hline & \multirow[t]{4}{*}{$1 \%$ Fenitrothion } & Baguida & 94 & 20.21 & [5.64-34.69] & Resistant \\
\hline & & Kolokopé & 100 & 100 & 100 & Susceptible \\
\hline & & Kovié & 103 & 98.05 & [95.82-100.26] & Susceptible \\
\hline & & Kisumu & 96 & 100 & 100 & Susceptible \\
\hline
\end{tabular}


Table 1 (continued)

\begin{tabular}{|c|c|c|c|c|c|c|}
\hline Year & Insecticides & Strain & $\mathbf{N}$ & Mortality (\%) & {$[95 \% \mathrm{Cl}]$} & Susceptibility status \\
\hline \multirow[t]{8}{*}{2013} & 5\% Malathion & Baguida & 99 & 73.73 & [59.79-88.33] & Resistant \\
\hline & & Kolokopé & 90 & 100 & 100 & Susceptible \\
\hline & & Kovié & 98 & 100 & 100 & Susceptible \\
\hline & & Kisumu & 95 & 100 & 100 & Susceptible \\
\hline & 0.4\% Chlorpyrisphos methyl & Baguida & 90 & 100 & 100 & Susceptible \\
\hline & & Kolokopé & 95 & 100 & 100 & Susceptible \\
\hline & & Kovié & 89 & 100 & 100 & Susceptible \\
\hline & & Kisumu & 102 & 100 & 100 & Susceptible \\
\hline \multirow[t]{32}{*}{2016} & $4 \%$ DDT & Baguida & 121 & 1.61 & {$[0.25-3.56]$} & Resistant \\
\hline & & Kolokopé & 69 & 0 & 0 & Resistant \\
\hline & & Kovié & 98 & 0 & 0 & Resistant \\
\hline & & Kisumu & 101 & 100 & 100 & Susceptible \\
\hline & 0.05\% Deltamethrin & Baguida & 123 & 17.03 & [10.39-23.21] & Resistant \\
\hline & & Kolokopé & 67 & 8.97 & [0.66-16.01] & Resistant \\
\hline & & Kovié & 91 & 4.4 & {$[1.53-8.27]$} & Resistant \\
\hline & & Kisumu & 92 & 100 & 100 & Susceptible \\
\hline & 0.75\% Permethrin & Baguida & 72 & 0 & 0 & Resistant \\
\hline & & Kolokopé & 93 & 10.75 & {$[5.13-25.69]$} & Resistant \\
\hline & & Kovié & 73 & 6.06 & {$[1.81-14.58]$} & Resistant \\
\hline & & Kisumu & 96 & 98.96 & [96.48-101.14] & Susceptible \\
\hline & 0.05\% Lambdacyhalothrin & Baguida & 121 & 16.53 & {$[4.7-26.24]$} & Resistant \\
\hline & & Kolokopé & 97 & 16.49 & {$[7.22-26.04]$} & Resistant \\
\hline & & Kovié & 88 & 2.27 & {$[1.66-5.1]$} & Resistant \\
\hline & & Kisumu & 90 & 98.89 & [97.15-100.92] & Susceptible \\
\hline & $0.1 \%$ Bendiocarb & Baguida & 111 & 2.7 & {$[0.95-4.55]$} & Resistant \\
\hline & & Kolokopé & 82 & 68.29 & {$[55.5-80.42]$} & Resistant \\
\hline & & Kovié & 81 & 1.23 & {$[0.92-2.85]$} & Resistant \\
\hline & & Kisumu & 87 & 98.85 & {$[95.65-101.41]$} & Susceptible \\
\hline & $0.1 \%$ Propoxur & Baguida & 75 & 6.67 & {$[1.37-11.46]$} & Resistant \\
\hline & & Kolokopé & 89 & 71.91 & [64.86-80.37] & Resistant \\
\hline & & Kovié & 99 & 8.08 & [4.58-10.67] & Resistant \\
\hline & & Kisumu & 83 & 98.80 & [95.38-101.5] & Susceptible \\
\hline & 1\% Fenitrothion & Baguida & 101 & 47.52 & [25.39-69.81] & Resistant \\
\hline & & Kolokopé & 89 & 100 & 100 & Resistant \\
\hline & & Kovié & 87 & 82.76 & [77.56-87.89] & Résistant \\
\hline & & Kisumu & 95 & 100 & 100 & Susceptible \\
\hline & 5\% Malathion & Baguida & 117 & 30.77 & [28.18-33.08] & Resistant \\
\hline & & Kolokopé & 89 & 100 & 100 & Susceptible \\
\hline & & Kovié & 99 & 92.93 & [84.66-98.9] & Suspected resistant \\
\hline & & Kisumu & 83 & 98.80 & [96.48-101.14] & Susceptible \\
\hline
\end{tabular}

$\mathrm{N}$, number of mosquitoes; $\mathrm{Cl}$, confidence interval

at $94{ }^{\circ} \mathrm{C}$ for $3 \mathrm{~s}$ followed by 35 cycles at $94{ }^{\circ} \mathrm{C}$ for $30 \mathrm{~s}$, a hybridization phase of $30 \mathrm{~s}$ at $55^{\circ} \mathrm{C}$ and $10 \mathrm{~s}$ at $72{ }^{\circ} \mathrm{C}$ with final elongation for $5 \mathrm{~min}$ at $72{ }^{\circ} \mathrm{C}$. The expected band sizes to distinguish resistant and susceptible in sibling species are: 293 bp fragment for the common band, $195 \mathrm{bp}$ for resistant allele and $137 \mathrm{bp}$ for susceptible allele.
Detection of the East African $k d r$ allele, L1014S followed the same procedure as described above. The following primers were used for amplification: Agd1 (5'ATA GAT TCC CCG ACC ATG-3'), Agd2 (5'-AGA CAA GGA TGA TGA ACC-3'), Agd4 (5'-CTG TAG TGA TAG GAA ATT TA-3'), and Agd5 (5'-ATT TGC ATT ACT TAC GAC TG-3'). Agd1, Agd2 were the common 
primers, Agd4 was the susceptible primer, and Agd5 the resistant primer.

The ace-1 G119S mutation was performed with the primers Ex3AGdir (5'-GAT CGT GGA CAC CGT GTT CG-3'), Ex3AGrev 5'-AGG ATG GCC CGC TGG AAC AG-3' which were amplified in the following conditions: DNA polymerase activation step at $94{ }^{\circ} \mathrm{C}$ for $3 \mathrm{~s}$ followed by 35 cycles at $94{ }^{\circ} \mathrm{C}$ for $30 \mathrm{~s}$, a hybridization phase for $30 \mathrm{~s}$ at $62{ }^{\circ} \mathrm{C}$ and $30 \mathrm{~s}$ at $72{ }^{\circ} \mathrm{C}$ with a final elongation at $72{ }^{\circ} \mathrm{C}$ for $5 \mathrm{~min}$. After amplification, the products $(5 \mu \mathrm{l})$ were analysed by electrophoresis on $2 \%$ agarose gel to verify the appearance of the expected first bands (541 bp). Fifteen microlitre of PCR product was digested with $5 \mathrm{U}$ of $A l u \mathrm{I}$ restriction enzyme in a final volume of $25 \mu \mathrm{l}$ at $37^{\circ} \mathrm{C}$ overnight.

Final products resulting from digestion were also analysed by electrophoresis to differentiate a 403 bp fragment for susceptible homozygous mosquitoes (SS), and two fragments of $253 \mathrm{bp}$ and $150 \mathrm{bp}$ for homozygous resistant (RR).

Samples from the localities accounting for the 3 years were analysed for the presence of $k d r-w$ and ace- 1 (except those from Kolokopé 2013). Regarding $k d r-e$, only samples from Baguida (2012 and 2013), Kovié (2013) and Kolokopé (2012) were analysed.

\section{Data analysis}

Knockdown times $\left(\mathrm{KDT}_{50}\right.$ and $\left.\mathrm{KDT}_{95}\right)$ along with $95 \%$ confidence intervals $(\mathrm{CI})$ were calculated using Polo Plus version 1.0 software. Mortality rates were calculated as the ratio between dead individuals and the total number of mosquitoes tested; $95 \% \mathrm{CI}$ of the mortality rates were calculated using Excel software (Microsoft Corp). The resistance status was determined using the WHO criteria [28]. The dynamics of the kdr 1014F frequency of each sibling species were compared between years using Fisher Exact test. The genotype frequencies of $k d r$ and ace-1 loci in sibling species were compared to HardyWeinberg expectations using Fisher exact test implemented in GenePop (version 4) software.

\section{Results}

\section{Knockdown times and mortality rates of Anopheles gambiae populations}

No knockdown times $\left(\mathrm{TKD}_{50}\right.$ and $\left.\mathrm{TKD}_{95}\right)$ were observed for DDT in none of the localities during the 3 years. For deltamethrin, the $\mathrm{TKD}_{50}$ and $\mathrm{TKD}_{95}$ were all high. They were recorded in individuals from Baguida regardless the year. They were 42.56 (CI [38.1848.28]) and 131.73 (CI [101.36-198.77]) in 2012, 24.71 (CI [22.4-27.12]) and 90.78 (CI [76.35-113.49]) in 2013, and 56.92 (CI [51.55-64.68]) and 203.99 (CI [154.86-304.06]), respectively. The KDTs of permethrin were also high and obtained in only Baguida and Kovié in 2016 (see Additional file 1: Table S1).

Mortality rates of An. gambiae s.l. are shown in Table 1. Mosquitoes were resistant to DDT in all the localities with the highest mortality $(15.55 \%$, CI [7.1622.96]) at Kovié; no mortality was recorded at Kolokopé (2012, 2013, 2016) and Kovié (2016). Resistance to pyrethroids was also observed in the three localities. The highest mortalities were recorded in 2013: deltamethrin (52\%, CI [46.71-56.64]) and lambdacyhalothrin (57.57\%, CI [51.15-64.69]) at Baguida, and permethrin (26.26\%, CI [14.5-39.68]) at Kovié. Regarding carbamates, mosquitoes were only susceptible to bendiocarb $(98.86 \%$, CI $[96.9-101])$ and suspected resistant to propoxur (97.93\%, CI [95.6-100.27]), both in 2013. Concerning organophosphates, mosquitoes were fully susceptible to chlorpyrifos methyl in all the localities during the 3-year survey, fully susceptible at Kolokopé (2013 and 2016) and suspected resistant (92.93\%, CI [84.66-98.9]) in 2016 at Kovié, both to malathion. Susceptibility to fenitrothion was observed at Kolokopé and Kovié in 2013, and at Kovié (98.05\%, CI [95.82-100.26]) in 2016. Kisumu, the laboratory strain was susceptible to all insecticides.

\section{Sibling species of Anopheles gambiae complex identified}

Species identification was carried in 914 individuals of An. gambiae complex (see Table 2). Overall, An. gambiae was the most common species (61.6\%) followed by $A n$. coluzzii (35.45\%). Anopheles arabiensis was less common (0.87\%). Hybrids (i.e., An. coluzzii/An. gambiae) were also identified (2.51\%).

In 2012, An. gambiae was more common at Baguida (99.44\%) and Kolokopé (98.77\%); An. arabiensis was less common (0.56\% at Baguida and $1.23 \%$ at Kolokopé). No An. coluzzii was identified at both localities. At Kovié, the most common species was the hybrid (57.17\%); An. coluzzii and An. gambiae were 37.93 and 6.9\%, respectively.

In 2013, An. gambiae was dominant in Baguida $(89.29 \%)$ and Kolokopé (50.36\%); An. arabiensis was $2.68 \%$ at Baguida and absent at Kolokopé. At Kovié, An. gambiae was $7.78 \%$ whereas An. coluzzii dominated (92.22\%); An. arabiensis was absent (Table 3).

In 2016, the proportion of An. gambiae was higher at Kolokopé (73.44\%) than at Baguida (50\%). Anopheles coluzzii was $50 \%$ at Baguida as well. Anopheles arabiensis was less common at Kolokopé and Kovié (3.13 and 1.45\%, respectively).

During the 3 years, hybrids were exclusively identified at Baguida (2013), Kovié (2012) and Kolokopé (2016) in proportions of $0.89 ; 57.17$ and $8.70 \%$, respectively. 


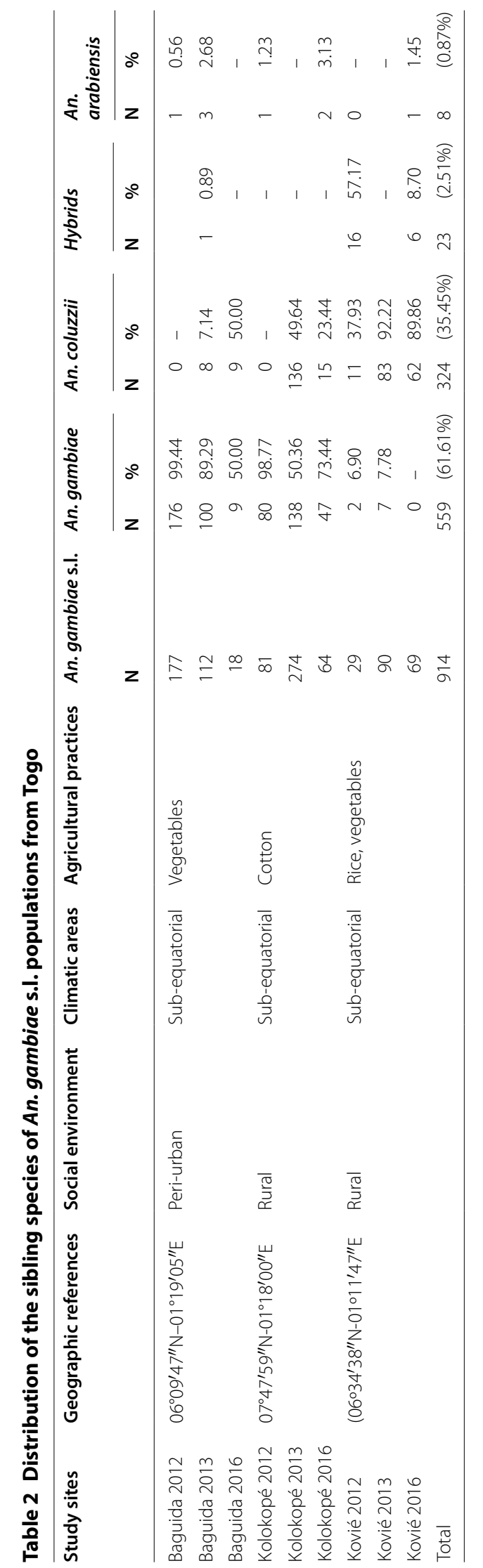


Table 3 Distribution and frequency of the L1014F knockdown resistance (kdr) alleles of An. gambiae s.l. populations from Togo

\begin{tabular}{|c|c|c|c|c|c|c|c|c|c|}
\hline \multirow[t]{3}{*}{ Species } & \multirow[t]{3}{*}{ Agricultural practices } & \multirow[t]{3}{*}{ Sites } & \multirow[t]{3}{*}{$\mathbf{N}$} & \multicolumn{3}{|c|}{ Genotypes } & \multirow[t]{3}{*}{$f(L 1014 F)$} & \multirow[t]{3}{*}[95\%\mathrm{Cl}]{} & \multirow[t]{3}{*}{$\mathrm{p}(\mathrm{HW})$} \\
\hline & & & & 1014L & 1014L & $1014 \mathrm{~F}$ & & & \\
\hline & & & & 1014L & $1014 \mathrm{~F}$ & $1014 \mathrm{~F}$ & & & \\
\hline \multirow[t]{4}{*}{ An. arabiensis } & Cotton & KOL 2012 & 1 & 0 & 0 & 1 & 0.98 & {$[0.71-1.25]$} & - \\
\hline & & KOL 2016 & 3 & 0 & 0 & 3 & 0.98 & {$[0.82-1.14]$} & - \\
\hline & Vegetables & BAG 2012 & 1 & 0 & 0 & 1 & 0.98 & {$[0.71-1.25]$} & - \\
\hline & & BAG 2013 & 2 & 0 & 0 & 2 & 0.98 & {$[0.79-1.17]$} & - \\
\hline \multirow[t]{6}{*}{ An. coluzzii } & Rice & KOV 2013 & 26 & 1 & 2 & 23 & 0.923 & {$[0.82-1.03]$} & 0.1167 \\
\hline & & KOV 2016 & 61 & 0 & 1 & 60 & 0.992 & {$[0.97-1.01]$} & - \\
\hline & Cotton & KOL 2013 & 133 & 49 & 1 & 83 & 0.628 & {$[0.55-0.71]$} & 0.0000 \\
\hline & & KOL 2016 & 15 & 1 & 0 & 14 & 0.933 & [0.80-1.06] & - \\
\hline & Vegetables & BAG 2013 & 2 & 0 & 0 & 2 & 0.98 & [0.79-1.17] & - \\
\hline & & BAG 2016 & 9 & 0 & 0 & 9 & 0.98 & [0.89-1.07] & - \\
\hline \multirow[t]{6}{*}{ An.gambiae } & Cotton & KOL 2012 & 60 & 0 & 0 & 60 & 0.98 & [0.94-1.02] & - \\
\hline & & KOL 2013 & 137 & 5 & 1 & 131 & 0.96 & [0.93-0.99] & 0.0000 \\
\hline & & KOL 2016 & 30 & 0 & 0 & 30 & 0.98 & [0.93-1.03] & - \\
\hline & Vegetables & BAG 2012 & 142 & 0 & 0 & 142 & 0.98 & [0.96-1.00] & - \\
\hline & & BAG 2013 & 62 & 0 & 0 & 62 & 0.98 & [0.95-1.01] & - \\
\hline & & BAG 2016 & 14 & 0 & 0 & 14 & 0.98 & [0.86-1.10] & - \\
\hline
\end{tabular}

KOV, Kovié; KOL, Kolokopé; BAG, Baguida; N, number of mosquitoes; $\mathrm{f}$ (L1014F), frequency of the L1014F resistant allele; Cl, confidence interval; p(HW), probability of the exact test for goodness of fit Hardy-Weinberg equilibrium

\section{Genotype of target site insensitivity mutations}

The $k d r 1014 \mathrm{~F}(\mathrm{kdr}-\mathrm{w})$ mutation frequency is shown in Table 3. In any case, the kdr 1014F frequency was $>0.9$ in An. gambiae and An. arabiensis regardless of year and locality. It was 0.98 at Kolokopé and Baguida in both species and 0.96 in An. gambiae at Kolokopé in 2013. In $A n$. coluzzii, the frequency was also $>0.9$ at all localities and in all years except at Kolokopé where it was 0.68 (CI [0.55-0.71]) in 2013. When kdr-w frequencies of all the localities were pooled together and sorted by year, the temporal distribution showed an increase of the frequency from 0.68 to 0.98 in An. coluzzii (see Table 4). This increase was especially observed at Kolokopé, which is a cotton-growing area (Table 3 ).

The frequency of $k d r 1014 \mathrm{~S}$ (kdr-e) was 0.043 in $A n$. gambiae from Kolokopé (2012) (Table 5). This mutation was not detected in samples from other localities.

The frequency of ace $1119 \mathrm{~S}$ was low in An. coluzzii at Kovié in 2013 (0.14, CI [0.03-0.24] and $2016(0.05$, CI $[0.00-0.19])$ and in hybrids $(0.063$, CI $[0.00-0.18])$

Table 4 Temporal distribution of 1014F kdr frequency in An. gambiae s.l. populations from Togo

\begin{tabular}{|c|c|c|c|c|c|c|c|}
\hline \multirow[t]{3}{*}{ Species } & \multirow[t]{3}{*}{ Year } & \multirow[t]{3}{*}{$N$} & \multicolumn{3}{|c|}{ Genotypes } & \multirow[t]{3}{*}{$f(L 1014 F)$} & \multirow[t]{3}{*}[95\%\mathrm{Cl}]{} \\
\hline & & & $1014 \mathrm{~L}$ & $1014 \mathrm{~L}$ & $1014 \mathrm{~F}$ & & \\
\hline & & & 1014L & $1014 \mathrm{~F}$ & $1014 \mathrm{~F}$ & & \\
\hline \multirow[t]{3}{*}{ An. arabiensis } & 2012 & 2 & 0 & 0 & 2 & 0.98 & {$[0.79-1.17]$} \\
\hline & 2013 & 2 & 0 & 0 & 2 & 0.98 & [0.79-1.17] \\
\hline & 2016 & 3 & 0 & 0 & 3 & 0.98 & [0.82-1.14] \\
\hline \multirow[t]{2}{*}{ An. coluzzii } & 2013 & 161 & 50 & 3 & 108 & 0.680 & {$[0.61-0.75]$} \\
\hline & 2016 & 85 & 1 & 1 & 83 & 0.982 & [0.95-1.01] \\
\hline \multirow[t]{3}{*}{ An.gambiae } & 2012 & 202 & 0 & 0 & 202 & 0.98 & [0.96-1.00] \\
\hline & 2013 & 199 & 5 & 1 & 193 & 0.972 & [0.95-0.99] \\
\hline & 2016 & 35 & 0 & 0 & 35 & 0.98 & [0.93-1.03] \\
\hline
\end{tabular}

$\mathrm{N}$, number of mosquitoes; $\mathrm{f}(\mathrm{L} 1014 \mathrm{~F})$, frequency of the $\mathrm{L} 1014 \mathrm{~F}$ allele; $\mathrm{Cl}$, confidence interval 
Table 5 Frequency of the L1014S knock down resistance (kdr) alleles of An. gambiae s.I. populations from Togo

\begin{tabular}{|c|c|c|c|c|c|c|c|c|c|}
\hline \multirow[t]{3}{*}{ Species } & \multirow[t]{3}{*}{ Agricultural practices } & \multirow[t]{3}{*}{ Sites } & \multirow[t]{3}{*}{$\mathrm{N}$} & \multicolumn{3}{|c|}{ Genotypes } & \multirow[t]{3}{*}{$f(L 1014 S)$} & \multirow[t]{3}{*}[95\%\mathrm{Cl}]{} & \multirow[t]{3}{*}{$p(H W)$} \\
\hline & & & & 1014L & 1014L & $1014 S$ & & & \\
\hline & & & & $1014 \mathrm{~L}$ & $1014 S$ & $1014 S$ & & & \\
\hline An. arabiensis & Vegetables & BAG 2012 & 1 & 1 & 0 & 0 & 0.000 & - & - \\
\hline An. coluzzii & Rice & KOV 2013 & 13 & 13 & 0 & 0 & 0.000 & - & - \\
\hline \multirow[t]{4}{*}{ An.gambiae } & Rice & KOV 2013 & 3 & 3 & 0 & 0 & 0.000 & - & - \\
\hline & Cotton & KOL 2012 & 23 & 22 & 0 & 1 & 0.043 & {$[0.00-0.13]$} & 0.024 \\
\hline & Vegetables & BAG 2012 & 36 & 36 & 0 & 0 & 0.000 & - & - \\
\hline & & BAG 2013 & 16 & 16 & 0 & 0 & 0.000 & - & - \\
\hline
\end{tabular}

KOV, Kovié; KOL, Kolokopé; BAG, Baguida; N, number of mosquitoes; $f(L 1014 S)$, frequency of the L1014S resistant allele; Cl, confidence interval; $p(H W)$, probability of the exact test for goodness of fit Hardy-Weinberg equilibrium

in 2012, and relatively higher in An. gambiae at Baguida in 2012 (0.52, CI [0.34-0.69]) and 2013 (0.66, CI [0.46$0.86]$ ) (Table 6). No An. arabiensis in the samples was found with ace-1 allele.

\section{Discussion}

This study showed that levels of insecticide resistance in Anopheles species are high in Togo, given the high knockdown times, the low mortality rates recorded, and the high allele frequencies. Mosquitoes were especially resistant to DDT and pyrethroids, which target the voltage-gate sodium channel in Anopheles populations. Findings in this study outline the presence of three sibling species of the malaria vector An. gambiae s.l. In those species, $k d r$ allele frequencies were high over the 3-year survey (An. gambiae and An. arabiensis) and increased significantly from 2013 to 2016 in An. coluzzii. This is the first time kdr 1014F mutation was observed in An. arabiensis at such a high frequency (i.e., $\mathrm{f}=0.98$ ). Knockdown resistance mutation was previously reported in An. gambiae (former S form) and An. coluzzii (former M form) in Togo [30]. This situation is evidence of the spread of $k d r$ resistance within Anopheles populations. This study focuses on three different agricultural areas: vegetable production (Baguida), rice cultivation (Kovié) and cotton production (Kolokopé). The development and spread of the resistance in malaria vectors has been attributed to intensive use of insecticides in agriculture, particularly in cotton cultivation [31-33]. The development of illegal insecticide-selling markets in rural areas also plays a key role in the resistance [9]. Agricultural practices create numerous trenches that retain rain and water from irrigation systems. In Cameroon, An. gambiae s.l. females were reported to frequently lay their eggs in breeding sites located around agricultural settings,

Table 6 Allelic and genotypic frequencies at the ace-1 locus in An. gambiae s.l. populations from Togo

\begin{tabular}{|c|c|c|c|c|c|c|c|c|c|}
\hline \multirow[t]{3}{*}{ Species } & \multirow[t]{3}{*}{ Agricultural practices } & \multirow[t]{3}{*}{ Sites } & \multirow[t]{3}{*}{$\mathrm{N}$} & \multicolumn{3}{|c|}{ Genotypes } & \multirow[t]{3}{*}{$f(119 S)$} & \multirow[t]{3}{*}[95\%\mathrm{Cl}]{} & \multirow[t]{3}{*}{$\mathrm{p}(\mathrm{HW})$} \\
\hline & & & & $119 \mathrm{G}$ & $119 G$ & $119 \mathrm{~S}$ & & & \\
\hline & & & & 119G & $119 \mathrm{~S}$ & $119 \mathrm{~S}$ & & & \\
\hline \multirow[t]{5}{*}{ An. coluzzii } & Rice & KOV 2012 & 11 & 11 & 0 & 0 & 0.000 & - & - \\
\hline & & KOV 2013 & 40 & 29 & 11 & 0 & 0.138 & {$[0.03-0.24]$} & 1.0000 \\
\hline & & KOV 2016 & 10 & 9 & 1 & 0 & 0.050 & {$[0.00-0.19]$} & - \\
\hline & Cotton & KOL 2016 & 9 & 9 & 0 & 0 & 0.000 & - & - \\
\hline & Vegetables & BAG 2016 & 1 & 1 & 0 & 0 & 0.000 & - & - \\
\hline \multirow[t]{5}{*}{ An. gambiae } & Rice & KOV 2012 & 2 & 2 & 0 & 0 & 0.000 & - & - \\
\hline & Cotton & KOL 2012 & 18 & 18 & 0 & 0 & 0.000 & - & \\
\hline & & KOL 2016 & 8 & 8 & 0 & 0 & 0.000 & - & - \\
\hline & Vegetables & BAG 2012 & 31 & 6 & 18 & 7 & 0.516 & [0.34-0.69] & 0.4850 \\
\hline & & BAG 2013 & 22 & 2 & 11 & 9 & 0.659 & {$[0.46-0.86]$} & 1.0000 \\
\hline Hybrid & Rice & KOV 2012 & 16 & 15 & 0 & 1 & 0.063 & [0.00-0.18] & 0.0341 \\
\hline
\end{tabular}


suggesting that larvae may undergo a selection pressure from agricultural pesticides that promotes the emergence of resistance [34]. Evidence for this assumption was recently reported in Burkina-Faso [35]. Agriculture is the main source of income for most of the population of Togo (70\%) [6] and to date agricultural practices are expanding in rural areas and in city outskirts. Indeed, many studies reported that in Togo crop protection practices are primarily based on the excessive use of synthetic pesticides, which in most cases includes pyrethroids and organophosphates [36, 37]. Agboyi et al. [37] reported that farmers still use organochlorides, although they are obsolete. In cotton and vegetable fields, insecticide residues are accumulated in the soil and during rainy seasons, breeding sites are permanently contaminated; larvae are then constantly under insecticide pressure.

Pyrethroid resistance in Anopheles population is worrying and it can compromise vector control strategies, such as the use of pyrethroid-only LLINs. In addition to the $\mathrm{kdr} 1014 \mathrm{~S}$ and $1014 \mathrm{~F}$ alleles identified in this study, Djègbè et al. [38] previously reported the presence of the $1575 \mathrm{Y}$ allele in An. coluzzii and An. gambiae from Kovié and Nangbéto, suggesting the situation is worsening. Furthermore, recent study conducted at Kolokopé showed high levels of resistance in An. gambiae s.l. (Ahadji-Dabla et al. pers. commun.). The frequency of kdr-east found at Kolokopé (2012) was 0.043, which is very low but not insignificant. This mutation was found for the first time at Nangbeto in 2015 [38], a locality pertaining to the same region as Kolokopé; suggesting that kdr-east mutation appeared in Anopheles populations of this region before being reported in 2018. Kdr-east allele was found in West Africa first in Benin in An. arabiensis [39] and then in Burkina Faso in An. coluzzii, An. gambiae, and An. arabiensis [40]. Recently, it was reported in both An. coluzzii and $A n$. gambiae in Togo [38]. In this study, it was identified only in An. gambiae. It could probably be present in other species.

Insensitive acetylcholinesterase was found in both An. coluzzii and An. gambiae, and in the hybrid form as well. The presence of this mutation in Anopheles population suggests resistance to organophosphates and/or carbamates, which are also used by farmers [37]. Ace-1 was found in An. coluzzii at Kovié (2013 and 2016) and the frequencies were lower than those of Baguida (2012 and 2013). The allele was also previously reported at Lomé [41] and Kovié and Nangbéto [39]. Unfortunately, the duplication of the copy number of ace-1 allele was reported for the first time at Kovié and was associated to carbamate resistance [42] and Baguida [43], suggesting the reinforcement and spread of this resistance. The situation is worrying because this could represent a serious threat for resistance management strategies [43].

Based on the results of this study and the previous ones, the alarm is being sounded, to draw the attention of decision-makers, especially the NMCP, to the urgent need of resistance management programme implementation.

\section{Conclusion}

The Anopheles gambiae s.l. population in Togo was resistant to almost all the insecticides during the 3-year survey except to some organophosphates. Three types of resistance alleles were identified such as 1014F, 1014S and 119S. These types of resistance, coupled with those reported previously, represent a serious concern and as such a strategy should be devised to successfully control malaria vectors in Togo.

\section{Additional file}

Additional file 1: Table S1. Knockdown times (KDTs) calculated after exposure of Anopheles gambiae s.I. to 4\% DDT, 0.05\% deltamethrin, and $0.75 \%$ permethrin.

\section{Abbreviations}

ace-1: insensitive acetylcholinesterase; CTAB: cetyl trimethyl ammonium bromide; DNA: desoxyribonucleic acid; DDT: dichlorodiphenyltrichloroethane; IRSS: Institut de Recherche en Sciences de la Santé; kdr: knock down resistance; LLIN: long-lasting insecticide-treated nets; NMCP: National Malaria Control Programme; PCR: polymerase chain reaction; PNLP: Programme National de Lutte contre le Palusisme; (RR): resistant homozygous; SINE 200: Short INterspersed Elements; (SS): susceptible homozygous; WHO: World Health Organization.

\section{Acknowledgements}

We acknowledge the community of the three localities. Authors are thankful to IRSS/Burkina Faso laboratory for molecular analyses of Anopheles species. ADA thanks Mr. Roger Sanou and Dr. Dari F. Yannick Da for their help. ADA received a scholarship from the Organization for Women in Science for the Developing World (OWSD). KMAD is thankful to Fulbright Visiting Scholar Program.

\section{Authors' contributions}

ADA, KMAD, and GKK participated in the design of the study and data analysis. $A D A, K M A D$, and YGA carried out the larval collection and bioassays. ADA, ASH, BY, DDS, and RB participated in the molecular and data analyses. ADA and KMAD drafted the manuscript. GKK, RTAO, and RKD critical reviewed the manuscript. All authors read and approved the final manuscript.

\section{Funding}

This work was partly supported by the Organization for Women in Science for the Developing World (OWSD) through a Ph.D. scholarship granted to the first author.

\section{Availability of data and materials}

All data generated or analysed during this study are included in this manuscript.

Ethics approval and consent to participate

Not applicable. 


\section{Consent for publication}

Not applicable.

\section{Competing interests}

The authors declare that they have no competing interests.

\begin{abstract}
Author details
${ }^{1}$ Department of Zoology and Animal Biology, Faculty of Sciences, University of Lomé, 01 B.P. 1515 Lomé 01, Togo. ${ }^{2}$ Biodiversity Institute \& Department of Ecology and Evolutionary Biology, University of Kansas, Lawrence, KS 66045, USA. ${ }^{3}$ Institut de Recherche en Sciences de la Santé/Centre Muraz, 01 BP 545, Bobo-Dioulasso 01, Burkina Faso. ${ }^{4}$ National Malaria Control Program/Ministry of Health, 01 B.P. 518 Lomé 01, Togo.
\end{abstract}

\section{Received: 6 February 2019 Accepted: 15 May 2019}

Published online: 22 May 2019

\section{References}

1. WHO. World malaria report, 2017. Geneva: World Health Organization; 2017

2. WHO. World malaria report, 2018. Geneva: World Health Organization; 2018.

3. PNLP. Programme national de lutte contre le paludisme. Rapport annuel, 2013. Togo.

4. PNLP. Programme National de Lutte contre le Paludisme. Rapport d'activités, 2006. Togo.

5. PNLP. Programme National de Lutte contre le Paludisme. Rapport annuel, 2016. Togo.

6. PNLP. Programme National de Lutte contre le Paludisme. Rapport d'activités, 2009. Togo.

7. Amoudji AD, Ahadji-Dabla KM, Konaté L, Ketoh GK, Apétogbo YG, Glitho IA, et al. Evaluation de l'efficacité des moyens de lutte antivectorielle utilisés dans les ménages au Togo. J Rech Sci Univ Lomé (Togo), Série A. 2015;17:63-78.

8. Ketoh KG, Morgah K, Akogbeto M, Faye O, Glitho IA. Insecticide susceptibility status of Anopheles populations in Togo. J Rech Sci Univ Lomé (Togo), Série A. 2005;7:13-22.

9. Ahadji-Dabla KM, Ketoh GK, Nyamador WS, Apetogbo GY, Glitho IA. Susceptibility to DDT and pyrethroids, and detection of knockdown resistance mutation in Anopheles gambiae sensu lato in Southern Togo. Int J Biol Chem Sci. 2014;8:314-23.

10. Ahadji-Dabla KM, Nyamador WS, Amoudji AD, Apétogbo YG, Oboussoumi KF, Aawi A, et al. Susceptibility of a malaria vector Anopheles gambiae s.l. (Diptera: Culicidae) to WHO recommended insecticides in Togo (West Africa). J Entomol Zool Stud. 2015;3:75-9.

11. Vulule JM, Beach RF, Atieli FK, McAllister JC, Brogdon WG, Roberts JM, et al. Elevated oxidase and esterase levels associated with permethrin tolerance in Anopheles gambiae from Kenyan villages using permethrinimpregnated nets. Med Vet Entomol. 1999;13:239-44.

12. Hemingway J, Hawkes NJ, McCarroll L, Ranson H. The molecular basis of insecticide resistance in mosquitoes. Insect Biochem Mol Biol. 2004;34:653-65.

13. Martinez-Torres $D$, Chandre F, Williamson M, Darriet F, Bergé J, Devonshire $A L$, et al. Molecular characterization of pyrethroid knockdown resistance $(\mathrm{kdr})$ in the major malaria vector Anopheles gambiae s.s. Insect Mol Biol. 1998;7:179-84.

14. Ranson H, Jensen B, Vulule J, Wang X, Hemingway J, Collins F. Identification of a point mutation in the voltage-gated sodium channel gene of Kenyan Anopheles gambiae associated with resistance to DDT and pyrethroids. Insect Mol Biol. 2000;9:491-7.

15. Weill M, Malcolm C, Chandre F, Mogensen K, Berthomieu A, Marquine M, et al. The unique mutation in ace-1 giving high insecticide resistance is easily detectable in mosquito vectors. Insect Mol Biol. 2004;13:1-7.

16. Padonou GG, Sezonlin M, Ossé R, Aizoun N, Oké-Agbo F, Oussou O, et al. Impact of three years of scale Indoor Residual Spraying (IRS) and Insecticide Treated Nets (ITNs) interventions on insecticide resistance in Anopheles gambiae s.l. in Bénin. Parasit Vectors. 2012;5:72.

17. Aïkpon $R$, Sèzonlin M, Ossè R, Akogbéto $M$. Evidence of multiple mechanisms providing carbamate and organophosphate resistance in field
Anopheles gambiae population from Atacora in Benin. Parasit Vectors. 2014;7:568.

18. Ngufor C, N'Guessan R, Fagbohoun J, Subramaniam K, Odjo A, Fongnikin A, et al. Insecticide resistance profile of Anopheles gambiae from a phase Il field station in Cové, southern Benin: implications for the evaluation of novel vector control products. Malar J. 2015;14:464.

19. Dabiré KR, Diabaté A, Namontougou M, Djogbénou L, Kengne P, Simard F, et al. Distribution of insensitive acetylcholinesterase (ace-1R) in Anopheles gambiae s.I. populations from Burkina Faso (West Africa). Trop Med Int Health. 2009;14:396-403.

20. Dabiré KR, Diabaté A, Namountougou M, Djogbénou L, Wondji C, Chandre $F$, et al. Trends in insecticide resistance in natural populations of malaria vectors in Burkina Faso, West Africa: 10 years' surveys. In: Perveen F, ed. Insecticides pest engineering. 2012. vol. 22, p. 479-502.

21. Dabiré RK, Namountougou M, Diabaté A, Soma DD, Bado J, Hyacinthe $\mathrm{K}$, et al. Distribution and Frequency of kdr Mutations within Anopheles gambiae s.l. Populations and First Report of the Ace.1G119S Mutation in Anopheles arabiensis from Burkina Faso (West Africa). PLoS One 2014;9:e101484.

22. Hunt RH, Fuseini G, Knwoles S, Stiles-Ocran J, Verster R, Kaiser ML, et al. Insecticide resistance in malaria vector mosquitoes at four localities in Ghana, West Africa. Parasit Vectors. 2011;4:107.

23. Baffour-Awuah S, Annan AA, Maiga-Ascofare O, Soma DD, Adjei-Kusi P, Owusu-Dabo E, et al. Insecticide resistance in malaria vectors in Kumasi, Ghana. Parasit Vectors. 2016:9:633.

24. Nwane P, Etang J, Chouaïbou M, Toto JC, Mimpfoundi R, Simard F. Kdrbased insecticide resistance in Anopheles gambiae s.s. populations in Cameroon. BMC Research Notes. 2011;4:463.

25. Antonio-Nkondjio C, Poupardin R, Fossog Tene B, Kopya E, Costantini C, Awono-Ambene P, et al. Investigation of mechanisms of bendiocarb resistance in Anopheles gambiae populations from the city of Yaoundé, Cameroon. Malar J. 2016;15:424.

26. Wandjala CL, Kweka EJ. Malaria vectors insecticides resistance in different agrosystems in Western Kenya. Front Public Health. 2018;6:55.

27. WHO. Tests procedures for insecticide resistance monitoring in malaria vectors, bioefficacy and persistence of insecticides on treated surfaces. Geneva: World Health Organization; 1998.

28. WHO. Test procedures for insecticide resistance monitoring in malaria vectors mosquitoes. Geneva: World Health Organization; 2013. p. 40.

29. Santolamazza F, Mancini E, Simard F, Qi Y, Tu Z, Torre A. Insertion polymorphisms of SINE200 retrotransposons within speciation islands of Anopheles gambiae molecular forms. Malar J. 2008;7:163.

30. Ketoh GK, Ahadji-Dabla KM, Dery D, Chabi J, Glitho IA, Brengues C, et al. Seasonal distribution and insecticide resistance in Anopheles gambiae s.l. in Lomé. Poster. 2009, 5th MIM Conference.

31. Elissa N, Mouchet J, Riviere F, Meunier JY, Yao K. Resistance of Anopheles gambiae s.s. to pyrethroids in Côte d'Ivoire. Ann Soc Belg Med Trop. 1993;73:291-4.

32. Diabate A, Baldet T, Chandre F, Akogbeto M, Guiguemde TR, Darriet F, et al. The role of agricultural use of insecticides in resistance to pyrethroids in Anopheles gambiae s.l. in Burkina Faso. Am J Trop Med Hyg. 2002;67:617-22.

33. Yadouleton $A$, N'Guessan $R$, Allagbé $H$, Asidi $A$, Boko M, Ossè R, et al. The impact of the expansion of urban vegetable farming on malaria transmission in major cities of Benin. Parasit Vectors. 2010;3:118.

34. Antonio-Nkondjio C, Fossog BT, Ndo C, Djantio BM, Togouet SZ, AwonoAmbene $\mathrm{P}$, et al. Anopheles gambiae distribution and insecticide resistance in the cities of Douala and Yaounde (Cameroon): influence of urban agriculture and pollution. Malar J. 2011;10:154.

35. Hien AS, Soma DD, Hema O, Bayili B, Namountougou M, Gnankine O, et al. Evidence that agricultural use of pesticides selects pyrethroid resistance within Anopheles gambiae s.l. populations from cotton growing areas in Burkina Faso, West Africa. PLoS One. 2017;12:e0173098.

36. Agboyi LK, Djade KM, Ahadji-Dabla KM, Ketoh GK, Nuto Y, Glitho IA. Vegetable production in Togo and potential impact of pesticide use practices on the environment. Int J Biol Chem Sci. 2015;9:723-36.

37. Mondedji AD, Nyamador WS, Amevoin K, Adéoti R, Abbey GA, Ketoh GK, et al. Analyse de quelques aspects du système de production légumière et perception des producteurs de l'utilisation d'extraits botaniques dans la gestion des insectes ravageurs des cultures maraîchères au Sud du Togo. Int J Biol Chem Sci. 2015;9:98-107. 
38. Djègbè I, Akoton R, Tchigossou G, Ahadji-Dabla KM, Atoyebi SM, Adéoti $\mathrm{R}$, et al. First report of the presence of L1014S Knockdown-resistance mutation in Anopheles gambiaess and Anopheles coluzzil from Togo, West Africa. Welcome Open Research. 2018;3:30.

39. Djègbè I, Boussari $O$, Sidick $A$, Martin T, Ranson $H$, Chandre F, et al. Dynamics of insecticide resistance in malaria vectors in Benin: first evidence of the presence of L1014S kdr mutation in Anopheles gambiae from West Africa. Malar J. 2011;10:261.

40. Namountougou M, Diabate A, Etang J, Bass C, Sawadogo SP, Gnankiné $\mathrm{O}$, et al. First report of the L1014S kdr mutation in wild populations of Anopheles gambiae M and S molecular forms in Burkina Faso (West Africa). Acta Trop. 2013;125:123-7.

41. Ahadji-Dabla KM, Amoudji AD, Dery DB, Apétogbo YG, Ketoh GK, Glitho IA. Susceptibility to carbamate and organophosphate, and ace-1 allele in Anopheles gambiae s.l. from pyrethroid resistance areas in the city of Lomé, Togo, West Africa. Int J Biol Med Res. 2017;6:5843-7.
42. Edi CV, Djogbenou L, Jenkins AM, Regna K, Muskavitch MA, Poupardin $R$, et al. CYP6 P450 enzymes and ACE-1 duplication produce extreme and multiple insecticide resistance in the malaria mosquito Anopheles gambiae. PLoS Genet. 2014;10:e1004236.

43. Assogba BS, Milesi P, Djogbenou LS, Berthomieu A, Makoundou P, BabaMoussa LS, et al. The ace-1 locus is amplified in all resistant Anopheles gambiae Mosquitoes: fitness consequences of homogeneous and heterogeneous duplications. PLoS Biol. 2016;14:e2000618.

\section{Publisher's Note}

Springer Nature remains neutral with regard to jurisdictional claims in published maps and institutional affiliations.
Ready to submit your research? Choose BMC and benefit from:

- fast, convenient online submission

- thorough peer review by experienced researchers in your field

- rapid publication on acceptance

- support for research data, including large and complex data types

- gold Open Access which fosters wider collaboration and increased citations

- maximum visibility for your research: over 100M website views per year

At BMC, research is always in progress.

Learn more biomedcentral.com/submissions 